\title{
Chinese Mapped America Before 1430
}

\author{
Siu-Leung Lee ${ }^{\mathrm{a}}$ \\ ${ }^{a}$ Zheng He Society of the Americas, Washington DC,USA, sllee19@gmail.com
}

\begin{abstract}
Qualitative and quantitative comparison of Kunyu Wanguo Quantu (the 1602 Chinese world map) and contemporaneous world maps by Mercator (1569), Ortelius (1570), Mercator's Arctic map (1595), and Plancius (1594) in particular, reveals that the Chinese map is not an adapted copy from European maps. The Chinese world map includes geography of a pre-Renaissance Europe and American geography unknown to Europeans until more than 200 years after Ricci's death. Approximately 50\% of the place names, including those of America, have no equivalents on European maps. Chinese names descriptive of the geographic feature of California peninsula, Mount Ranier, the fjords of Alaska, Mount Denali, tidal bore near Anchorage are all accurate by latitudes. Chile and Peru are correct by relative longitude. Contrarily, the maps by Plancius and Mercator are erroneous and ambiguous on the geography of North and South America. The geography and text of the Chinese world map are consistent with a completion date of 1430, some sixty years before Christopher Columbus' first voyage. Martino Martini's Novus At- las Sinensis (1655) is not a survey of his own but translated from Chinese sources, revealing that Ming China was capable of determining longitude/latitude on land and ocean, as well as spherical projection. In conclusion, information about American geography was transferred from China to Europe, not the reverse. The Chinese world map Kunyu Wanguo Quantu is the result of Chinese circumnavigation and survey, pioneering the Age of Exploration, overturning 600 years of misinterpreted history.
\end{abstract}

Keywords: Kunyu Wanguo Quantu, Matteo Ricci, Zheng He, Age of Exploration.

\section{Introduction}

In 1602, the Italian Jesuit priest Matteo Ricci presented to the Chinese Emperor Wanli a world map 坤舆萬國全 圖 (坤輿万国全图 Kunyu Wanguo Quantu) labeled entirely in Chinese. For the past 400 years, the Chinese world map has been thought to be a map translated from European sources. At $1.52 \mathrm{~m}$ high and $3.66 \mathrm{~m}$ wide, with 1114 place names, the Chinese world map is the most detailed and accurate world map of its time. In 2010, University of Minnesota purchased a copy of the map (Ricci, Li and Zhang 1602). A high resolution copy is also available from the websites of Library of Congress (Ricci 1602a) and a color version from Tohoku University (Ricci 1602b) (Figure 1). Nicknamed "Impossible Black Tulip", the Chinese world map has puzzled cartographers for decades be- cause of its surprisingly accurate information of regions not yet known to European explorers of the time. For easier discussion, the map is referred to as the 1602 Chinese world map, but it is not drawn by Matteo Ricci and the survey was mostly completed prior to 1430 as the evidence unfolds.

\section{The $\mathbf{1 6 0 2}$ World map is not adapted from European maps}

There are many clues showing that the 1602 Chinese world map is not derived from European maps of Ricci's time (S.-L. Lee 2012a, 2012b, 2015, 2016). Some of the key points are: (1) The Papal States, Tuscany, and Florence are absent, and the names of Hibernia, Lutetia are outdated Roman names for Ireland and Paris, respectively; (2) Fifty percent of the place names including those of the Americas have no equivalent on European drawn maps (Huang and Gong 2004, 183-209); (3) Pasquale M. d'Elia (1890-1963) translated many place names into Italian, rather than obtaining them directly from European sources (d'Elia 1938); and (4) The 1602 Chinese world map accurately labels the oceans by the cardinal direction centred on China while the nomenclature in European maps at that time is confusing. On a globe constructed by Ulpius (Siebold 2015), the ocean west of Mexico is named "Oceanus Orientalis et Occidentalis". On Ortelius' Maris Pacifici (1590), Mar del Nort appears at southern tip of South Amer- ica. On Aleni's world map (Aleni 1623), Atlantic Ocean is both Great West Ocean and Great East ocean. Buache's Carte des Nouvelles Découvertes (Buache 1753) refers to the ocean north of the equator as South Sea (Au Nord de la Mer de Sud).

In this paper, more qualitative and quantitative analyses of selected regions of America and China are presented to substantiate the following:

1) The 1602 world map is the result of China's own survey, rather than a copy of European maps.

2) China had the necessary cartographical technology to plot longitude and latitude of large areas in spherical projection. 


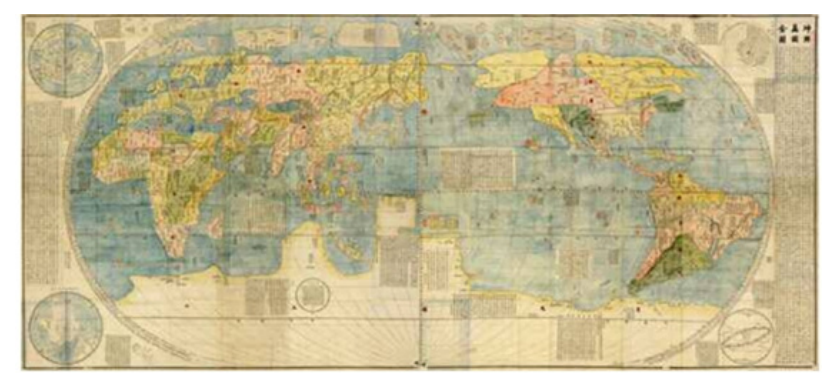

Figure 1. Kunyu Wanguo Quantu, Tohoku University Library, Japan.

\section{The prime meridian and longitude}

Mercator, Ortelius, and Plancius, as well as other maps in the 16th century set the prime meridian at either Canary Islands $\left(13-18^{\circ} \mathrm{W}\right)$ or Cape Verde Islands $\left(22-25^{\circ} \mathrm{W}\right)$, with a variation of anywhere from $100 \mathrm{~km}$ to $900 \mathrm{~km}$ offshore of continental Africa. For the 1570 world map of Ortelius, the prime meridian is set at about $23^{\circ} \mathrm{W}$ of Green- wich. It is not logical to set up the prime meridian at some small islands in the middle of the Atlantic, introducing difficulties and inaccuracy to measurements on an open ocean. Setting the prime meridian on some islands off in the big ocean began with Ptolemy's map which shows only 180 degrees in longitude, i.e. half of the globe. It is ques- tionable how Ptolemy, who stayed in Alexandria for most if not all his life created this prime meridian standard. The next question is whether Christopher Columbus understood that he had to travel half of the globe to reach China.

These fundamental questions should be puzzling for all cartographers.

The 1602 Chinese world map aligns the prime meridian with multiple points of West Africa about $16-17^{\circ} \mathrm{W}$, e.g. Dakar, Senegal $\left(17^{\circ} 33^{\prime} 22^{\prime \prime} \mathrm{W}\right)$. The westernmost region of Africa is a much more logical prime meridian as the beginning of the Asia-Europe-Africa land mass. West of the continental mass is the Atlantic Ocean, or Great West Ocean by Chinese. This significant difference in the prime meridian shows that the 1602 Chinese map is not derived from maps by Ortelius, Mercator and Plancius.

\section{Western North America, Chinese world map vs Plancius' 1594 map}

Many names on the west coast of North America are not available on Ortelius' Theatrum Orbis Terrarum (1570) and Mercator's Nova et aucta orbis terrae descriptio ad usum navigantium em (1569), both thought to be the blue- prints of the Chinese world map. Plancius' Orbis Terrarum (1594) is the first world map with the western North America labeled comparably to the Chinese world map, yet there is no available record of European exploration of the state of Washington, western Canada and Alaska prior to 1594. The official exploration of the western frontier starts with Lewis and Clark's journey (1804-1806), reaching Oregon.

The following is a critical comparison of northwestern America of the 1602 Chinese world map and Plancius' map (Table 1. Western North America. Chinese world map vs 1594 Plancius map.). The contemporary latitude and longitude data are from satellite data of Google Earth. All longitude values are adjusted to degrees west of Greenwich for easy comparison. The labeling on ancient maps does not allow precision better than within two degrees.

Thus, all coordinates are rounded to the closest units.

Specifically, three names are chosen, viz. 水潮峰 (Shui Chao Feng, Tidal Bore Mountain), 美灣 (Mei Wan, Beautiful Bay), and 雪山 (Xue Shan, Snow Mountain), corresponding to C. de Corrientes, B. Hermosa, and C. Blanco on the Plancius 1594 map respectively. The deviation of specific locations on the Plancius map compared to the geography today is consistently 3 to 5 fold higher than the 1602 Chinese map. For comparison, the distance across the US is about $4200 \mathrm{~km}$.

\begin{tabular}{|c|c|c|c|c|c|c|}
\hline \multirow{3}{*}{ Anchorage } & \multicolumn{2}{|c|}{ Latitude ${ }^{\circ} \mathrm{N}$} & \multicolumn{3}{|c|}{ Longitude ${ }^{\circ} \mathrm{W}$} & \multirow{2}{*}{$\begin{array}{c}\text { Distance } \\
\mathrm{km}\end{array}$} \\
\hline & & $\Delta$ & Original & Adjusted & $\Delta$ & \\
\hline & 61.22 & - & 149.9 & & - & .. \\
\hline 水朝峰 Tidal Bore Mt. & 60 & 1 & 215 & 162 & 12 & 670 \\
\hline C. de Corrientes & 60 & 1 & 183 & 200 & 50 & 2690 \\
\hline C. de Corrientes & 42 & 19 & 188 & 195 & 45 & 3623 \\
\hline Ketchikan (Misty Fjord) & 55.34 & _- & 131.65 & & -- & .. \\
\hline 美湾 Beautiful Bay & 55 & 0 & 228 & 149 & 17 & 1108 \\
\hline B.Hermosa & 52 & 3 & 192 & 191 & 61 & 3791 \\
\hline B.Hermosa & 40 & 15 & 200 & 183 & 51 & 4088 \\
\hline R.Hermosa $^{1}$ & 33 & 22 & 222 & 161 & 30 & 3308 \\
\hline Hermosa & 27 & 28 & 245 & 138 & 6 & 3112 \\
\hline Mount Ranier & 46.85 & _- & 121.76 & & $\ldots$ & .. \\
\hline 雪山 Snow Mountain & 46 & 1 & 235 & 142 & 20 & 1554 \\
\hline C. Blanco & 55 & 12 & 188 & 195 & 73 & 4930 \\
\hline C. Blanco & 41 & 6 & 195 & 188 & 66 & 4879 \\
\hline Sierra Nevada ${ }^{2}$ & 41 & 6 & 208 & 175 & 53 & 4865 \\
\hline C. Blanco & 35 & 12 & 214 & 169 & 47 & 4044 \\
\hline C. Blanco & 30 & 17 & 226 & 157 & 35 & 3533 \\
\hline
\end{tabular}

Table 1. Western North America. Chinese world map vs 1594 Plancius map.

In good weather conditions, Denali is visible at Anchorage from the inlet of Turnagain Arm. At over $6000 \mathrm{~m}$, the highest mountain of North America is normally hidden behind clouds, only visible $30 \%$ of the time even to Anchor- age residents. Turnagain Arm, the only tidal bore on the entire American west coast, is a natural wonder only prominent during certain phases of the moon. To observe both the Denali and the tidal bore and name it Tidal Bore Mountain, one would need to be stationed there for some time. Denali was first sighted by Vancouver in 1794 and Turnagain Arm named by William Bligh in 1778 under Captain Cook's command. The 1602 Chinese world map includes both geographic features almost 200 years before Vancouver and Cook. The inaccurate interpretation of tidal bore (macareo) as current (corrientes) shows that the original naming was not Spanish. Today, Cabo Corrientes in Jalisco, Mexico has no geographical feature of a tidal bore or a high mountain.

Mount Ranier $\left(46.85^{\circ} \mathrm{N}, 121.76^{\circ} \mathrm{W}\right)$, the highest mountain $(4392 \mathrm{~m})$ and the icon of the state of Washington, is visible from hundreds of kilometers from the ocean. It easily qualifies as Snow Mountain (雪山) for its year-round snow cap. Another possible location on the Plancius map is Sierra Nevada marked at $41^{\circ} \mathrm{N}, 175^{\circ}$ $\mathrm{W}$ in the middle of Pacific Ocean, rather than $38^{\circ} \mathrm{N}, 119^{\circ}$ W. The name Sierra Nevada (Snow Mountain in Spanish) was given to an interior mountain by Juan Rodríguez 
Cabrillo in 1542 to describe a Pacific Coast Range. Sailing as far north as $40^{\circ} \mathrm{N}$, the Cabrillo crew could not have seen Mount Ranier which was first sighted by George Vancouver in 1792.

Jedediah Smith is the first European to reach Sierra Nevada in 1827, more than 220 years after the 1602 Chinese world map.

Beautiful Bay (美灣) could be any one of the beautiful fjords from Ketchikan $\left(55^{\circ} \mathrm{N}, 129^{\circ} \mathrm{W}\right)$ to Glacier Island

$\left(60^{\circ} \mathrm{N}, 147^{\circ} \mathrm{W}\right)$. If Tidal Bore Mountain (Anchorage) and Snow Mountain (Mount Ranier) fit perfectly by their latitude on the 1602 Chinese world map, there is reason to believe that Beautiful Bay is near Ketchikan, the first fjord seen by from north bound ships for its picturesque scenery and the deep, calm and sheltering bay for navigation.

The multiple locations by the same name on Plancius map are off substantially by latitude and longitude. There are three labels of B. Hermosa (R. Hermosa is likely a transcriptional error of B. Hermosa), two locations labeled C. de Corrientes (Tidal Bore Mountain), four C. Blanco (White Mountain for Snow-top Mountain) and one Sierra Nevada (Snow Mountain in Spanish). This is the result of uncertainty of the cartographer receiving ambiguous information from multiple sources. A true explorer would not confuse the reader by assigning the same name to different neighboring locations.

\section{Erroneous maps of California}

California is one of the last states explored. The error of Mercator's Arctic map (1595) placing California in the Arctic Circle contradicts his earlier map of 1569. The 1602 Chinese map shows California at the correct location in both the main map and the Arctic inset. The head of Gulf of California on 1602 Chinese world map at $5^{\circ}$ north of current latitude could be explained partly by the continued deposit of silt from Colorado River over 600 years (See Table 2).

\begin{tabular}{|c|c|c|c|c|c|c|}
\hline & \multicolumn{2}{|c|}{ Latitude $^{\circ} \mathrm{N}$} & \multicolumn{3}{|c|}{ Longitude ${ }^{\circ} \mathrm{W}$} & \multirow{2}{*}{$\begin{array}{r}\text { Distance } \\
\text { km } \\
\end{array}$} \\
\hline & & $\Delta$ & Original & Adjusted & $\Delta$ & \\
\hline 2016 Satellite survey & 31.17 & -- & & 114.58 & -. & -. \\
\hline 1602 Chinese map & 36 & 5 & 254 & 123 & 11 & 969 \\
\hline 1595 Mercator Arctic & 69 & 38 & 214 & 168 & 54 & 6155 \\
\hline 1594 Plancius & 37 & 6 & 253 & 132 & 18 & 1765 \\
\hline
\end{tabular}

Table 2. Head of Gulf of California compared

Gulf of California was named Mar de Cortés by Ulloa in honour of his patron Hernando Cortés (1540). However, the map by Girolamo Ruscelli (1561) and Ortelius' Mar Pacifici (1590) label it as Mar Bermejo (Mar Vermejo, Red Sea) just as the 1602 Chinese world map calls it East Red Sea 东红海 (to distinguish it from West Red Sea 西 红海 next to Sinai Peninsula, using China as the reference).

The Glen McLaughlin Map Collection at Stanford University keeps more than 700 maps from 1622 until mid 1800s portraying California as an island (Stanford University 2016).

A map by Herman Moll (1741) still shows California as an island extending to $46^{\circ} \mathrm{N}$. A small Pacific Ocean and a narrow Strait of Anian (before Bering Strait was named) separate Asia from America. Alaska is labeled as "Parts Unknown" and Pacific Ocean north of the equator is erroneously labeled as the Great South Sea.

That California is not an island was only confirmed by Jesuit Eusebio Francisco Kino in 1699, more than one hundred years after Ortelius and Mercator who seem to get it right without exploration. Scientifically speaking, there is no such thing as "mental discovery". The only possibility is Ortelius and Mercator obtained the information else- where.

\section{Arctic Canada, Chinese world map vs Plancius}

On the 1570 map of Ortelius, forty years before Henry Hudson's voyage, an unnamed bay (supposedly the unknown Hudson Bay) appears with a wide opening to the Arctic Circle. Before Hudson Bay was discovered and named after Henry Hudson in 1610, it already had a name 哥泥白斯湖 (Lake Conibas or Conibaz), a large bay with a narrow inlet which should be how it appears to the explorer entering from the north. Lago de Conibaz appears on Plancius 1594 map and Conrad Löw's "Book of Sea Heroes" (1598). The absence of any European explo- ration effort before the appearance of geography has been pointed out by Bancroft as "imaginary", "accidental", "fictional", and "stronger than holy writ" (Bancroft 1886, 85-87). More unreasonable is the Mercator's map of the Arctic Circle (1595), where Lago Conibaz (Conibas) drains into the Gulf of California situated in the Arctic Circle while another unnamed bay opens to the Arctic Circle. These discrepancies and lack of exploration records are clearly resulting from hearsay rather than actual survey.

On the Chinese world map, 何皮六河 (Obilo River) is a large river meandering into Arctic Ocean. This is equivalent to Mackenzie River (1789) named after the discover Alexander Mackenzie, 190 years later. On Mercator's 1595 map, Obilo River is misspelled as Obila flu, draining into Gulf of California in the Arctic Circle.

The Plancius map shows two rivers flowing into the Arctic, but there is only one Obilo River (Mackenzie River). Thus, it is only incidental that one of them appears to be more accurate by longitude and latitude (Table 3). Besides, Henry Hudson could only reach Hudson Bay in 1610 when Mackenzie River was not even known.

A bridge over Mackenzie River completed in 2013 bears the native name "Deh Cho" (the Big River), which is phonologically the same as Chinese 大漕 (Dai Cho in Southern dialect commonly used in Ming dynasty) implying Chinese influence in the native name. Obilo River could be navigable during the warmer period of Zheng He's voyages (1405-1433), after which a minor ice age prevented the "Northwest Passage". European explorers could not reach Mackenzie River until the nineteen century when more advanced technology was available. 


\begin{tabular}{|c|c|c|c|c|c|}
\hline & \multicolumn{2}{|l|}{ Latitude $\mathrm{N}$} & \multicolumn{2}{|c|}{ Longitude } & \multirow{2}{*}{$\begin{array}{r}\text { Distance } \\
\mathrm{km}\end{array}$} \\
\hline & & $\Delta$ & Original & Adjusted $\Delta$ & \\
\hline 2016 Satellite survey & 69.36 & - & & $133.9-$ & -- \\
\hline 1602 Chinese map & 70 & 1 & 268 & 10925 & 987 \\
\hline 1594 Plancius & 70 & 1 & 245 & 1384 & 202 \\
\hline 1594 Plancius & 75 & 5 & 203 & $180 \quad 46$ & 1623 \\
\hline
\end{tabular}

Table 3. Coordinates of Mouth of Mackenzie River compared

The geography of the 1602 Chinese world map is far more accurate than the maps by Ortelius, Mercator and Plancius. Matteo Ricci in China from 1582 to 1610 could not have made any improvement on their maps, even with the help of Plancius.

\section{1602 Chinese world map results from Chinese Survey}

The latitudes of place names on the Plancius map and the 1602 Chinese map are presented in Table 4. Xuntien (顺 天府 Shuntianfu) on the Plancius map is off to the north by 8 degrees latitude. Xuntienfu is named by Zhu Di (Emperor Yongle) as the administration in Beijing in 1403. The absence of Shuntienfu in Ortelius 1570 and appearance in Plancius 1594 shows that information of Yongle's China was acquired by European cartographers between 1570 and 1594 .

\begin{tabular}{|c|c|c|c|c|c|c|c|}
\hline \multirow{2}{*}{$\begin{array}{l}1594 \\
\text { Plancius }\end{array}$} & \multirow{2}{*}{$\begin{array}{l}1602 \\
\text { Chinese map }\end{array}$} & & \multicolumn{5}{|c|}{ Latitude ${ }^{\circ} \mathrm{N}$} \\
\hline & & & \multicolumn{2}{|c|}{ Current Plancius $\Delta_{\text {ex }}$} & \multicolumn{3}{|c|}{ Chinese $\Delta_{\text {crinewe }}$} \\
\hline Xuntien顺天府 & 京师 & Jinqshi (Beijinq) & 40 & 48 & 8 & 40 & 0 \\
\hline Tayhiva fu & 太原 & Taiyuan Fu & 37.8 & 44 & 6.2 & 37 & -0.8 \\
\hline Chinan & 济南 & Jinan & 36.7 & 43 & 6.3 & 37 & 0.3 \\
\hline Caifon fu & 开封 & Kaifenq & 34.8 & 39 & 4.2 & 34 & -0.8 \\
\hline Hinthine fu & (应天府) & (Ningtian Fu) & 32 & 35 & $B$ & NA & NA \\
\hline Nanqin & 南京 & Nanjinq & 32 & 32 & 0 & 32 & 0 \\
\hline Fucheu fu & 福州 & Fuzhou & 26.1 & 27 & -0.9 & 26 & -0.1 \\
\hline Quilin fu & 桂林 & Guilin & 25.2 & 25 & -0.2 & 25 & -0.2 \\
\hline Hiuna fu & 云南(昆明) & Yunnan & 24.9 & 27 & 2.1 & 24 & -0.9 \\
\hline Seuchin & 揫庆 & Zhaoqing & 23 & 24 & 1 & 23 & 0 \\
\hline Canton & 广刚 & Guanqzhou & 23 & 24 & 1 & 23 & 0 \\
\hline Ainao & 海南 & Hainan & 20 & 19 & -1 & 19 & -1 \\
\hline
\end{tabular}

Table 4. Cities of China, 1602 Chinese map and Plancius 1594 compared.

\section{Westernmost point of South America}

In Figure 2, maps of South America are compared. Visually, the 1602 Chinese map is clearly closer to the satellite survey photo than maps by Ortelius and Plancius.

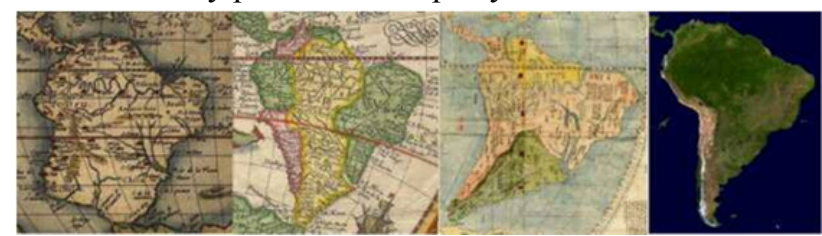

Figure 2. The shape of South America compared, left to right: Ortelius (1570), Plancius (1594), Ricci (1602b) and Satellite photo by NASA/Jet Propulsion Lab (2003).

The quantitative comparison is shown in Table 5. The Ortelius 1570 map erroneously assigns the westernmost point to Chile rather than Peru while the Chinese world map clearly shows the correct assignment.

The significant improvement of Plancius 1594 over Ortelius 1570 still falls short of the Chinese world map. This improvement is unaccounted for by Spanish exploration in this period. The Spanish were stopped at Valparaiso by Rio Bio Bio and fierce resistance of the native Mapuche until the 19th century.
When Magellan passed the strait of South America in 1520, he did not hug the coastline as an explorer would do to ensure provision. He headed directly towards northwest as if he knew the direction to reach Asia. He could have done that only if he had information from people who had actually crossed the Pacific. If Magellan did survey the coast of Chile, the results would have been reflected on the maps of Mercator and Ortelius.

\begin{tabular}{|c|c|c|c|c|c|}
\hline & Latitude ${ }^{\circ} \mathrm{S}$ & \multicolumn{2}{|c|}{ Lonqitude ${ }^{\circ} \mathrm{W}$} & \multirow[b]{2}{*}{$\Delta$} & \multirow{2}{*}{$\begin{array}{l}\text { Dist. } \\
\mathrm{km}\end{array}$} \\
\hline & $\Delta$ & Original & Adjusted & & \\
\hline 2016 Satellite surveyt & 4.68 & 81.33 & & & \\
\hline 1602 Chinese map & 4 & 286 & 90 & 9 & 964 \\
\hline 1570 Ortelius & 43 & 282 & 101 & 20 & 4690 \\
\hline 1594 Plancius & 7 & 286 & 97 & 16 & 1638 \\
\hline
\end{tabular}

Table 5. Westernmost point of South America

\section{Surveying technology of China, Martino Martini's Novus Atlas Sinensis}

That China could map the open ocean prior to European contact is supported by Novus Atlas Sinensis by Martino Martini. Martino Martini visited China at the worst time (1643-1651) during the transition of Ming to Qing dynasty. Upon returning to Europe, Martino Martini published Novus Atlas Sinensis (Blaeu and Blaeu 1655) including 17 maps and more than 1500 indexed names with longitude and latitude down to degrees and minutes. The map of Chi- na, Korea and Japan with defined latitude, longitude and spherical projection is shown in Figure 3. Map of China and Japan from Novus Atlas Sinensis by Martino Martini.

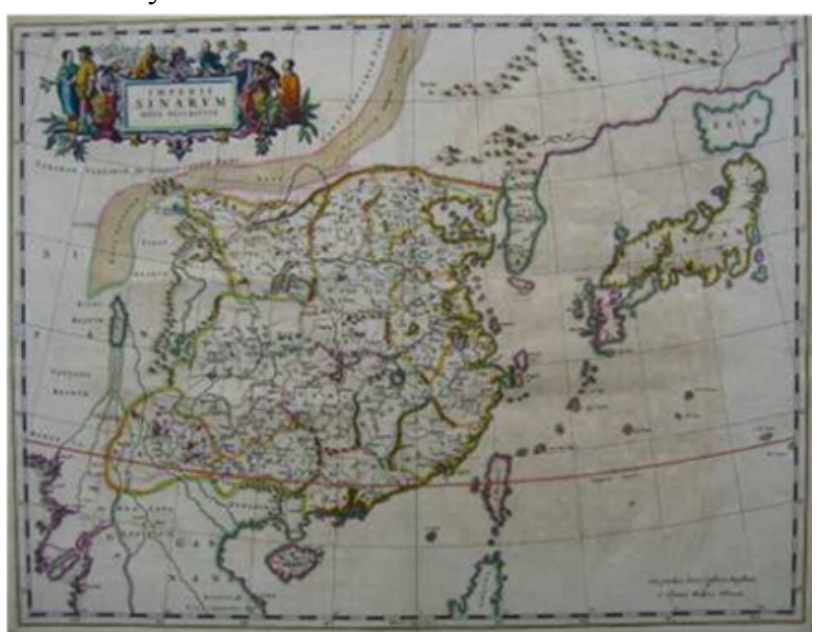

Figure 3. Map of China and Japan from Novus Atlas Sinensis by Martino Martini (Blaeu and Blaeu 1655).

For comparison, it took five years (1763-1767) and more than 100 people to survey the Mason-Dixon Line, a straight line of less than $400 \mathrm{~km}$. It is technically impossible for anybody to survey $6,000,000 \mathrm{sq} \mathrm{km}$ of territory in less than 10 years, especially during the most turbulent period of Ming-Qing transition. As long as one place name was not surveyed by Martini, it must be based on Chinese survey technology. The accurate longitude, latitude, and spherical projection have to be the work of thousands of Chinese surveys over hundreds of years. Error! Reference source not found. shows that the longitude and latitude for 19 selected cities in Novus Atlas Sinensis are within 1 degree deviation of satellite 
surveys in most cases. Even Seoul and Pyongyang in Korea deviate by only 0.5 degree in latitude. The longitudes of these foreign cities deviate more, understandably.

Martino Martini is known to have brought Chinese atlases back to Europe (Reed and Demattè 2011, 188).

Among them is Luo Hongxian's Guangyutu (罗洪先广與 图 Extensive Terrestrial Atlas), a Ming-dynasty atlas with 113 maps with description by Luo Hongxian in 1541, first printed in 1555 and updated in 1579. Xuntien Fu 顺 天府 $\left(39.9^{\circ} \mathrm{N}\right)$ was established and named by Emperor Yongle, implying the atlas was constructed during or after Yongle's reign.

\begin{tabular}{|c|c|c|c|c|c|c|c|c|c|}
\hline \multirow{2}{*}{$\begin{array}{l}\text { Name } \\
\text { NAS }^{1}\end{array}$} & \multirow{2}{*}{$\begin{array}{l}\text { Current Name } \\
\text { Chinese }\end{array}$} & \multirow[b]{2}{*}{ Euglish } & \multicolumn{4}{|c|}{ Longitude } & \multicolumn{3}{|c|}{ Latitude ${ }^{4}$} \\
\hline & & & NAS & Current & $\operatorname{Deg}_{x i}{ }^{2}$ & $\Delta$ & NAS & Current & $\Delta$ \\
\hline Xuntien & 洦天烸, 北京 & Beijing & 0.0 & 116.4 & 0 & 0 & 4000 & 3954 & 0.00 \\
\hline Cinan & 山东济丽 & Jinan, Shandong & E0.5 & 117.1 & E0.7 & 0.2 & 3700 & 3639 & 0.35 \\
\hline Caifung & 河南开封 & Kaifeng, Henan & 2.9 & 114.3 & 2.1 & 0.8 & 3550 & 3447 & 1.05 \\
\hline Chingtu & 四川成都 & Chengdu, Sichuan & 11.6 & 104.1 & 12.3 & 0.7 & 3047 & 3034 & 0.22 \\
\hline Vuchang & 湖北式夏 & Wuchang, Hubei & 3.3 & 114.3 & 2.1 & 1.1 & 3100 & 3033 & 0.45 \\
\hline Nanchang & 江西南三 & Nanchang, Jiangxi & 1.6 & 115.9 & 0.5 & 1.1 & 2913 & 2840 & 0.55 \\
\hline Nanking & 江苏莁京 & Nanjing, Jiangeu & E1.3 & 118.8 & E2.4 & 1.1 & 3204 & 3204 & 0.00 \\
\hline Sucheu & 江苏苏州 & Suzhou, Jiangsu & E3.5 & 120.6 & E4.2 & 0.7 & 3152 & 3118 & 0.57 \\
\hline Hangcheu & 浙江机班 & Hangzhou, Zhejiang & E3.2 & 120.1 & E3.7 & 0.5 & 3017 & 3016 & 0.02 \\
\hline Focheu & 㖶建福班 & Fuzhou, Fujian & E2.7 & 119.3 & E2.9 & 0.2 & 2558 & 2604 & 0.10 \\
\hline Quangcheu & 厂宋广州 & Guangzhou, Guangdong & 4.0 & 113.3 & 3.1 & 0.9 & 2358 & 2307 & 0.85 \\
\hline Chaoking & 厂柰影庆 & Zhaoging, Guangdong & 4.8 & 112.9 & 3.5 & 1.3 & 2330 & 2302 & 0.47 \\
\hline Queilin & 厂西桂林 & Guilin, Guangxi & 7.5 & 110.2 & 6.2 & 1.3 & 2554 & 2514 & 0.67 \\
\hline Gueiyang & 费州费阳 & Griyang, Guizhou & 11.8 & 106.6 & 9.8 & 2.0 & 2600 & 2638 & 0.63 \\
\hline Fumin ${ }^{3}$ & 云南昆明 & Kumming, Yumnan & 14.6 & 102.8 & 13.6 & 1.0 & 2503 & 2452 & 0.18 \\
\hline Dali & 云南大球 & Dali, Yumnan & 16.9 & 100.3 & 16.1 & 0.8 & 2527 & 2536 & 0.15 \\
\hline Leaoyang & 江宁江阳 & Liaoyang, Liaoning & E5. 5 & 123.2 & E6.8 & 1.3 & 3930 & 4116 & 1.77 \\
\hline Kingki & 首尔(弯特) & Seoul, Korea & E7.7 & 129.0 & E12.6 & 4.9 & 3800 & 3734 & 0.43 \\
\hline Pinggan & 平壊 & Pyongyang, Korea & E6.8 & 126.7 & E10.3 & 3.5 & 3900 & 3831 & 0.48 \\
\hline
\end{tabular}

Table 6. Cities in Novus Atlas Sinensis (NAS) compared to current survey.

\section{The survey of 1602 Chinese world map was completed before 1430}

On the 1602 Chinese world map, a text above Spain indicates that the map is drawn "some 70 years after the first communication with Europe". "Communication" here refers to diplomatic relationship which was first established when Giovanni de' Marignolli led a Papal legation to China and stayed from 1342 to 1347 . Seventy some years later (1415-1426) is within the time period of Zheng He's major voyages, when the statement was made and the map drawn. On the contrary, if the map was drawn by Ricci adapting Ortelius-Mercator maps, seventy some years before that would fall in a period of China's maritime ban (1433-1567) when communication was impossible, contradicting the statement on the map (S.-L. Lee 2012a). This unedited statement offers the most definitely dating of the map.

The China section of the world map includes places only relevant to Emperor Yongle (1403-1424), such as places along his route of campaigns against Mongolians and the spot he died which has no political or economic value in Wanli's era. The name 交趾 (Jiao Zhi) was changed to 安 南 (Annan) as a result of withdrawal of Ming's administration from Vietnam in 1428. Thus, the information of Chinese geography on the Chinese world map is consistent with a time period shortly after 1428 and before 1430 when Zheng He launched the last voyage.

\section{Conclusion}

By the time this paper is published, three more papers would have appeared in "Science of Surveying and Mapping", the official journal of Chinese Academy of Surveying and Mapping, lending the following evidence:

1) A Chinese world map labeling Canada and Apalchen (etymological origin of Appalachian) existed in Nan- jing before construction of the 1602 map. This shows Chinese knew about Canada and Apalchen before the new continent was known to Europe as "America".

2) By Ricci's own account about the map in his journal, he had very limited involvement in making the Chinese world map. Versions of the map were kept from Ricci's sight and he did not even own a copy.

3) Li Zhizao, the co-author who translated some European place names on the map, did not update Chinese geography which is much earlier than his time period.

Kunyu Wanguo Quantu, the 1602 Chinese world map, is labeled entirely in Chinese. It is either translated from European maps or based on original Chinese surveys and records.

Nicknamed "Impossible Black Tulip", Kunyu Wanguo Quantu is much more accurate and detailed than maps by Ortelius, Mercator and Plancius. Ricci could not have updated American geography known only 200 years before their "discovery". Ricci can be further excluded as an author because the pre-Renaissance geography and absence of Papal States in Europe are incompatible with Ricci's status as a Jesuit of Renaissance Italy. Since Ricci's collabora- tor Li Zhizao did not update the geography of China, the survey must be completed by Chinese well before Ricci and Li's time.

The geography of China on Kunyu Wanguo Quantu is pre-1430. The original Kunyu Wanguo Quantu should be a summary of surveys during Admiral Zheng He's first six voyages (1405-1424) to prepare for the last voyage. After Zheng He's death in 1433, China did not have the incentive and support for world exploration or construction of world maps.

Misunderstanding in the past 400 years stems from the fact that Matteo Ricci and Li Zhizao added colophons and place names to an original 1430 Chinese world map likely by the same name Kunyu Wanguo Quantu. The contribution of Ricci and $\mathrm{Li}$ is not on geographical survey but preservation of this precious map under a very delicate political situation of Ming China.

During the dynastic transition and wars with foreign powers, the original Chinese archive of Zheng He's voyages was lost. The missing information is now recovered from maps. Knowing that the Chinese world map was completed in 1430 rather than 1602 , it is comprehensible that the improvement of Plancius 1594 map over Ortelius 1570 map is really due to the flow of information from China to Europe, not the reverse. It is 
likely that fragmentary in- formation of the early Chinese voyages leaked by seamen along the routes triggered world explorations by Colum- bus and others.

The currently available evidence offers strong support to credit Ming Chinese for launching the Age of World Exploration and advancing cartography, overturning 600 years of misinterpreted history. Comparative cartography is proven a powerful tool to correct world history.

\section{Acknowledgements}

The author thanks Zheng He Society of the Americas and Rho Psi Foundation, both in Washington DC, for partial support for this presentation.

\section{References}

Aleni, G.(1623). Zhifang waiji, the first Western Atlas printed in China. Martayan Lan. http://martayanlan.com/images/Worldlarge.jpg. Accessed Oct 8, 2016.

Bancroft, H. H. (1886). The works of Hubert Howe Bancroft: History of the northwest coast. History Co, Blaeu, W.J. \& Blaeu, J. (1655). Novus Atlas Sinensis. University of Heidelberger historische bestände digital.

http://digi.ub.uni-

heidelberg.de/diglit/blaeu1655bd6/0015. Accessed Sep 30, 2015.

Buache, P. (1753). Carte des nouvelles decouvertes. Barry Lawrence Ruderman Antique Maps Inc. https://www.raremaps.com/gallery/detail/31701.

Accessed Oct 8, 2016.

d'Elia, P. M. (1938). Il mappamondo cinese del p. Matteo Ricci, S.I. Vatican: Bibl. Apostolica Vaticana. Huang, S. \& Gong Y. (2004). A study iof Ricci's world map. Shanghai: Shanghai Guji Publishing Co.

黄时鑒,龚缨晏 (2004). 利玛窦世界地图研究. 上海: 上 海古籍.

Lee, S-L. (2012a). Zheng He's voyages revealed by Matteo Ricci's world map. In S. C. Lin, S. K. Church (Eds.),

Zheng $\mathrm{He}$ and the Afro-Asian World (pp.307-335). Singapore: International Zheng He Society.

Lee, S-L.(2012b). Kunyu Wanguo Quantu Jiemi Mingdai Cehui Shijie. [Deciphering Kunyu Wanguo Quantu- Ming China Mapped the Woirld]. Taipei: Linking. 李兆良(2012b).坤舆萬國全圖解密-明代測繪 世界. 台北:聯經出版社,

Lee, S-L. (2015). Maps that turn world history upside down. Midwestern Epigraphic Society Journal 26-29, 424.

Lee, S-L. (2016). Kunyu Wanguo Quantu, A Chinese World Map - Matteo Ricci is not the Author. Science of Surveying and Mapping, 41(7): 59-66.

\section{李兆良(2016). 明代中国人环球测绘《坤舆万国全图》}

- 兼论坤舆万国全图的作者不是利玛窦.测绘科学, 41(7): 59-66.
Mercator, G. (1595). Antique map of Arctic/North Pole by Mercator. Antique Maps. http://www.helmink.com/Antique_Map_Mercator_Arcti c/. Accessed Oct 8, 2016.

Mercator, G. (1569). Nova et aucta orbis terrae descriptio ad usum navigantium em. Biblioteque Nationale de France.

http://gallica.bnf.fr/ark:/12148/btv1b7200344k.r=Nova $\% 20$ et\%20Aucta\%20Orbis\%20Terrae\%20Descriptio?rk =42918;4. Accessed Sep 20, 2016.

Moll, H. (1741). A New Map of North America According to the Newest Observations. California as an Island in Maps. https://exhibits.stanford.edu/californiaas-an-island/catalog/yn959jw9550. Accessed Sep 14, 2016.

NASA/Jet Propulsion Lab (2003). South America, Shaded Relief and Colored Height. Photojournal. http://photojournal.jpl.nasa.gov/catalog/PIA03388.

Accessed Oct 10, 2016.

Ortelius, A. (1590). Antique map of Pacific by Ortelius. Antique Maps. https://www.raremaps.com/gallery/enlarge/33385gm. Accessed Oct 8, 2016.

Ortelius, A. (1570). Theatrum Orbis Terrarum. Bibliothèque Nationale de France. http:/gallica.bnf.fr/ark:/12148/btv1b23004674/f1.item.r $=$ Theatrum $\% 20$ Orbis\%20Terrarum. Accessed May 4, 2016.

Plancius, P. (1594). Orbis Terrarum Typus De Integro Multis In Locis Emendatus auctore Petro Plancio. Barry Lawrencce Ruderman Antique Maps. https://www.raremaps.com/gallery/enlarge/22172. Accessed Sep 20, 2016.

Reed, M.\& Demattè, P. (2011). China on Paper: European and Chinese Works from the Late Sixteenth to the Early Nineteenth Century.

Los Angeles: Getty Publications.

Ricci, M. (1602a). Kun yu wan guo quan tu 1602. US Library of Congress. http://www.loc.gov/item/2010585650. Accessed Aug 13, 2015.

Ricci, M. (1602b). Kunyu Wanguo Quantu [Konyo bankoku zenzu]. Tohoku University Library 東北大学 附属図書館狩野文庫。 http://www.irepository.net/contents/tohoku/kano/ezu/kon/kon.html. Accessed Feb 21, 2017.

Ricci, M., Li, Z., Zhang W. (1602). World Map of 1602. James Bell Ford Library, University of Minnesota. https://www.lib.umn.edu/bell/riccimap. Accessed Aug 13,2015

Ruscelli, G.(1561). Nueva Hispania Tabul Barry Lawrence Ruderman Antique Maps Inc. https://www.raremaps.com/gallery/detail/32734/Nueva Hispania_Tabula_Nova/Ruscelli.html. Accessed Oct $\overline{2}$, 2015.

Siebold, J. (2015). Ulpius Globe. Cartographic Images. 
http://www.myoldmaps.com/renaissance-maps-1490-

1800/367-the-ulpius-globe/. Accessed Feb 21, 2017.

Stanford University (2016). California as Island in Maps. Maps from the Glen McLaughlin Collection of California as an island. https:/exhibits.stanford.edu/california-as-anisland/catalog/yc810rj3545. Accessed Sep 14, 2016. 